\title{
RESOURCE-EFFICIENT PROCESS CHAINS TO MANUFACTURE PATIENT-SPECIFIC PROSTHETIC FINGERS
}

\author{
D. Hagedorn-Hansen ${ }^{1 *}$, G.A. Oosthuizen ${ }^{1} \&$ T. Gerhold ${ }^{2}$
}

\section{ARTICLE INFO}

\section{Article details}

Submitted by authors 29 Jun 2015

Accepted for publication 6 Dec 2015

Available online

\section{Contact details}

* Corresponding author devonh@sun.ac.za

Author affiliations

1 Department of Industrial Engineering, University of Stellenbosch, South Africa

2 Department of Mechanical Engineering, University of Johannesburg, South Africa

DOI

http://dx.doi.org/10.7166/27-1-1279

\section{ABSTRACT}

The high cost of quality prostheses, together with the lack of trained prosthetists, makes it challenging to obtain prosthetic devices in developing communities. Modern $3 \mathrm{D}$ digitising techniques and additive manufacturing (AM) technologies are gaining popularity in the bio-medical industry and, in the case of prosthesis production, reduce the need for a trained prosthetist. The objective of this research was to develop a new resource-efficient process chain for the manufacturing of prosthetic fingers using additive manufacturing technologies, and to compare it with the traditional (Sculptor) process chain. Fused deposition modelling (FDM), open-source FDM, 3-dimensional printing (3DP), and stereolithography (SLA) were evaluated in terms of their costs, time, material usage, and aesthetic quality. The surface qualities produced with the different additive manufacturing technologies were also compared. The results showed that 3DP was the preferred technology and was the best candidate for the production of prosthesis in terms of cost, quality, and time for developing communities. SLA produced the highest aesthetic quality prosthesis, but was the most expensive. It was concluded that using the additive manufacturing technology process chain to produce prosthetic fingers is faster and more cost effective than the traditional method.

\section{OPSOMMING}

Die hoë kostes van gehalte prosteses, en die toegang tot opgeleide prostese vervaardigers, maak dit 'n uitdaging om prostetiese toestelle in ontwikkelende gemeenskappe te bekom. Moderne 3D digitaliserings tegnieke en toevoeging vervaardiging (AM) tegnologie is besig om in die bio-mediese bedryf gewild te raak en, in die geval van prostese produksie, kan dit die behoefte aan 'n opgeleide prostese vervaardigers beperk. Die doel van hierdie navorsing was om 'n nuwe hulpbron doeltreffende proses ketting vir die vervaardiging van prostetiese vingers met behulp toevoeging vervaardiging tegnologie te ontwikkel en om dit te vergelyk met die tradisionele proses ketting. Saamgesmelte afsetting modellering (FDM), 3-dimensionele druk (3DP) en stereolithography (SLA) is geëvalueer in terme van hul kostes, tyd, materiaal verbruik en estetiese gehalte. Die geproduseerde oppervlak eienskappe van die verskillende toevoeging vervaardiging tegnologieë is ook vergelyk. Die resultate het getoon dat 3DP die voorkeur-tegnologie en die beste kandidaat vir die produksie van prostese in terme van koste, kwaliteit en tyd vir die ontwikkeling van gemeenskappe was. SLA het die hoogste estetiese gehalte prostese vervaardig, maar was die duurste. Die gebruik van $A M$ tegnologie binne die waardeketting om prostetiese vingers te produseer, is vinniger en meer koste-effektiewe as die tradisionele metode. 
Since the industrial revolution, manufacturing has been regarded as the primary contributor to economic growth and development, as it stimulates the primary and tertiary sectors of the economy. The base of the pyramid (BoP) represents a socio-economic group of four billion people who live on less than US\$2.50 per day. In order to stimulate growth through manufacturing, the communities that fall into the BoP category must be considered, not only as a potential market, but also as potential producers. Therefore, most business strategies are currently promoting the development of goods and services to address the issues of poverty and sustainable development at the base of the pyramid according to Oosthuizen et al. [1].

According to Bartolo et al. [2] an increasing number of prosthetics are required for developing communities that fall into the BoP category. Vorvick [3] defines a prosthesis as an artificial replacement of a part of the body which can be designed for function, aesthetics, or both. Prostheses are traditionally manufactured through either a series of mould-making procedures with the use of prototypes, or through crude methods of hand-carving available materials. Both manufacturing processes require either a skilled sculptor or high-cost machinery and software. Research from Burger and Maricek [4] and Desmond and MacLachlan [5] shows that limited funds and skills in developing regions mean that people who have a deformation or a missing limb do not have access to high-quality prosthetics, and as a result they are often found to be affected by depression, low self-esteem, and in extreme cases suicidal ideation. Carroll and Fyfe [6] and Pillet [7] report that after the face, the hands are the principal representation of the self-image that is received by other individuals.

The number of journal articles by Carrol and Fyfe [6], Botolin [8], Biddiss [9], Quinton and Pilley [10], and Oosthuizen, Hagedorn-Hansen and Gerhold [11] relating to prosthetic devices suggests that the subject is well-researched. The studies, however, are largely focused on lower limb prostheses, and on highly functional and complex control systems for upper extremity prostheses. There is a lack of research on the development of new production methods of facial or hand prostheses. The traditional process chain for sculpting prosthetic fingers starts with taking impressions of the contralateral and affected side. These impressions are then cured and cast into a clay or wax model, which is used as a reference to sculpt the prototype. A mould is then manufactured using the prototype, and filled with bio-compatible silicone to produce the prosthesis, which then undergoes post-processing to ensure the desired aesthetic quality according to Oosthuizen, Hagedorn-Hansen, and Gerhold [11] and Liacouras et al. [12].

According to Quinton and Pilley [10] making use of modern methods of 3D scanning (3D digitising) and additive manufacturing (AM) technologies for the production of prostheses has proven to be successful. Gibson, Rosen, and Stucker [13] define additive manufacturing as the process of joining materials to make objects from 3D model data, usually layer upon layer, as opposed to subtractive cutting processes (e.g. milling). In order to lower the costs of prostheses, an open-source 3D printing machine (RapMan) was used in a process chain for this experiment. Open-source technology is freely available to download and does not require one to buy the product or expensive licences. Interested parties are granted access to the intellectual property (IP), designs, or software source code, and can actively participate in the product's development, thus enabling co-creation of value suggests Ueda et al. [14].

The objective of this research was to develop a resource-efficient process chain for the manufacturing of prosthetic fingers using additive manufacturing technologies and to compare it with the traditional process chain. Fused deposition modelling (FDM), open-source FDM, 3-dimensional printing (3D printing), and stereolithography (SLA) were evaluated in terms of costs, time, material usage, and aesthetic quality. The surface qualities produced with the different additive manufacturing technologies were also compared.

\section{ADDITIVE MANUFACTURING TECHNOLOGIES}

Since the Fablab revolution, and thanks to the collaborative open-source movement, numerous rapid product development technologies have been invented. This has also lowered the costs of other available technologies such as 3D scanning and 3D printing. 3D scanning enables a 3D object to be copied, recreating it in a digital format. This technique is particularly useful for digitising complex, organic geometries according to Scott, Wohlers, and Caffrey [15]. The laser line scanner 
enables the generation of surface digitisation data that can then be reconstructed into a CAD model. Laser scanners can be integrated with coordinate measurement machines (CMM), which originally used a tactile probe to obtain surface data according to Van Gestel et al. [16].

A laser line scanner directs a laser plane on to the surface to acquire data. As the scanner traverses the object, the plane of laser light intersects the surface of the object to form an intersection curve, and a camera collects the data from this curve. Shu and Xi [17] add that the coordinates of the points comprising of the intersection lines are then determined via triangulation. This data then forms the digitised surface data, which is typically displayed in the STL file format and can be converted to a surface that can be manipulated in a CAD package.

In this study a Kreon KLS51 laser line scanner attached to a Zeiss coordinate measurement machine (CMM) was used to scan a finger. The integrated system combines the advantages of a CMM and a laser scanner, for a faster and non-contact method of surface digitisation that allows for very high scan resolutions according to Van Gestel et al. [16] and Shu and Xi [17]. There are many different types of additive manufacturing machines that can fabricate parts using non-metal materials. Table 1 shows some of the commonly-used AM technologies in the medical field.

Table 1: The development years of AM technologies used in the medical industry (adapted from Levy, Schindel, and Kruth [18])

\begin{tabular}{|l|l|l|l|l|}
\hline Name & Acronym & $\begin{array}{l}\text { Development } \\
\text { years }\end{array}$ & Material & $\begin{array}{l}\text { Commercial } \\
\text { machine }\end{array}$ \\
\hline Stereolithography & SLA & $1986-1988$ & Photopolymer & $\begin{array}{l}\text { ProJet 6000 - 3D } \\
\text { Systems }\end{array}$ \\
\hline $\begin{array}{l}\text { Fused deposition } \\
\text { modelling }\end{array}$ & FDM & $1988-1991$ & Thermoplastics, metals & $\begin{array}{l}\text { Dimension Elite - } \\
\text { Stratasys }\end{array}$ \\
\hline 3D printing & 3DP & $1985-1997$ & $\begin{array}{l}\text { Specialised powder and } \\
\text { binder materials }\end{array}$ & $\begin{array}{l}\text { ProJet 260 3D } \\
\text { Systems }\end{array}$ \\
\hline
\end{tabular}

Commercial stereolithography (SLA) machines make use of an ultra-violet (UV) laser to solidify UVcurable resins through the photo-polymerisation process. The part is built layer by layer, and each layer is formed as the laser traces over the UV-curable resin. As the photopolymer material is exposed to the laser, the material cures and solidifies. Once the laser has scanned a particular layer, the build platform drops down by a distance equal to one layer's thickness. The recoating blade then deposits a new layer of resin to be solidified. The layers bond together and this process is repeated until the part is complete as stated by Jacobs [19], and Tang [20].

The fused deposition modelling (FDM) process builds parts layer by layer, where each layer is constructed by depositing a filament of material in a point-wise fashion. The thermoplastic filament is fed into a heating chamber and melted. A set of rollers pushes the material into the heating chamber, and it is this flow of material into the constant volume heating chamber that then produces the required pressure for extrusion. Once a layer has been completed, the build platform or the extrusion head will shift, either one layer down or up, depending on the machine setup, and the next cross-section is then deposited according to Gibson, Rosen, and Stucker [13]. Open-source FDM machines have become very popular since the initial launch of the RepRap machine.

Gibson, Rosen, and Stucker [13] state that the 3D printing (3DP) process makes use of a binder liquid, approximately $80 \mu \mathrm{m}$ in diameter, which drops on to a powder bed and binds the composite powder. Once a layer has been formed, the feeding tray that contains the feed powder shifts up by one layer, and the build tray in which the part is built shifts down by one layer's thickness. A new layer of powder is then distributed on to the previously-formed layer via a counter-rotating roller. The process is repeated until the final part has been completely formed according to Gibson, Rosen, and Stucker [13]. 
The research steps that were taken are discussed below.

First, a process chain that can be used to produce a prosthetic finger using $3 \mathrm{D}$ digitising techniques and additive manufacturing technologies was established. Then the time, cost, material usage, and quality throughout the process chain, using each of the four different $A M$ technologies, were determined. The prosthetic fingers were then produced using the four different $A M$ processes. During the production process the times for each process were measured along with the material usage. Once the fingers had been produced, the costs and aesthetic qualities of each of the fingers were compared with a traditionally-produced prosthetic finger. Finally, the surface roughness parameters of the surfaces produced via open-source FDM, commercial FDM, 3DP, and SLA technologies were determined.

\subsection{Cost calculations}

A cost model was developed based on the work of Gibson, Rosen, and Stucker [13]. Manual labour costs for the proposed process chain were ignored in this study, because a highly-skilled worker is not required for post-processing operations, which are only a small fraction of the total processing time. The cost of an AM build is a function of the purchase price of the machine per part $\left(C_{p}\right)$, the operation cost $\left(C_{o}\right)$, and the material costs $\left(C_{m}\right)$ shown in equation (1):

$$
C=C_{p}+C_{o}+C_{m}
$$

The machine purchase costs and the maintenance costs of the $A M$ machines must be split over the number of parts according to a specific time period. For the purchase cost the assumption is that the full price of the machine will be recovered over five years as stated by Atzeni and Salmi [21]. For the operation costs, the assumption is made that maintenance will be paid over the full lifetime of the machine. If the machine operates for 12 hours a day ( 0.5 days) and the build time, in hours, for a particular build is denoted by $T_{b}$, then the purchase price of the machine per part $\left(C_{p}\right)$ is given by equation (2).

$$
C_{p}=\frac{\text { PurchasePrice } \times T_{b}}{0.5 \times 24 \times 365 \times 5}
$$

The operation cost $\left(C_{o}\right)$ for the part is a function of the maintenance costs paid annually over the life of the machine, and the cost of electricity used for the build. The assumption is made that the maximum power of the machine is used for the duration of the build. For the case of SLA, where the laser needs to be replaced every 10,000 hours at a cost of approximately R300 000, this needs to be incorporated into the equation. The assumption of R0.7985/kWh from Eskom [22] for electricity costs is used for the calculations. The operation cost per part is shown in equation (3).

$$
C_{o}=T_{b}\left[\frac{\text { AnnualMaintenanceCost }}{0.5 \times 24 \times 365}+\frac{\text { LaserCost }}{10000}+P \times 0.7985\right]
$$

The power used for the build is calculated from the maximum power $(\mathrm{kWh})$ derived from equation (4):

$$
P=V I
$$

The material cost $\left(C_{m}\right)$ is simply calculated by multiplying the number of units of the material by the cost per unit of material, as shown in equation (5).

$$
C_{m}=C_{u} \times U_{m}
$$

\subsection{Quality inspection}

The surface topography measurements give an indication of the consistency of the layer deposition process and the surface roughness of the moulds. The Hommel T8000 surface roughness machine was used to measure the surfaces of the different moulds. The setup for the machine can be seen in Figure 1 below. 


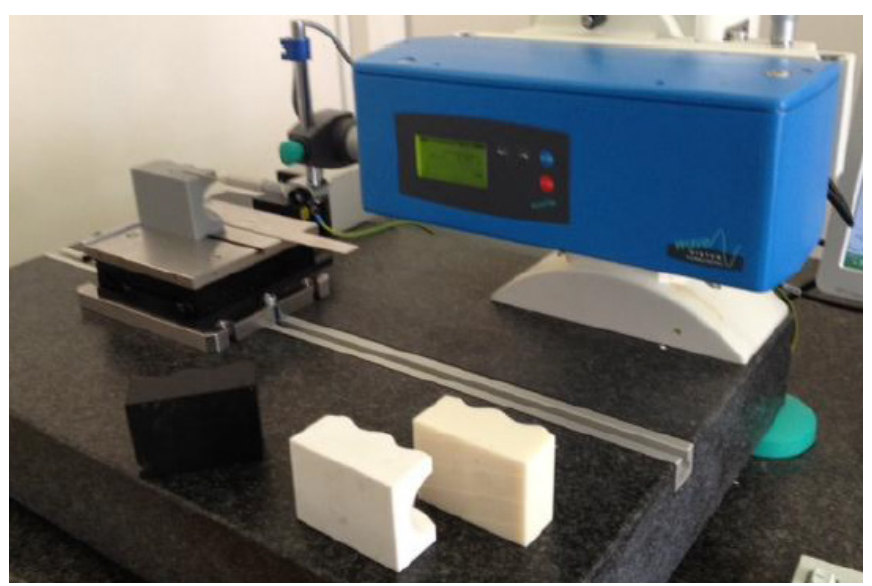

Figure 1: Setup of Hommel-Etamic T8000 surface roughness machine to measure the waviness profile of the moulds

In order to compare the aesthetic quality of the final prosthesis, a skilled prosthetist visually inspected the different prosthesis and ranked them accordingly. The following criteria were used: smooth surfaces, fine features, defects, and realistic enough to pass off as a real finger.

\section{EXPERIMENTAL RESULTS AND DISCUSSION}

\subsection{Process chain comparison}

First, the process chain of the traditional manufacturing method for a prosthetic finger was compared with the suggested resource-efficient process chain to determine the resource efficiency of the newly-developed method. The typical process chain for developing a prosthetic finger in developed regions is shown in Figure 2.

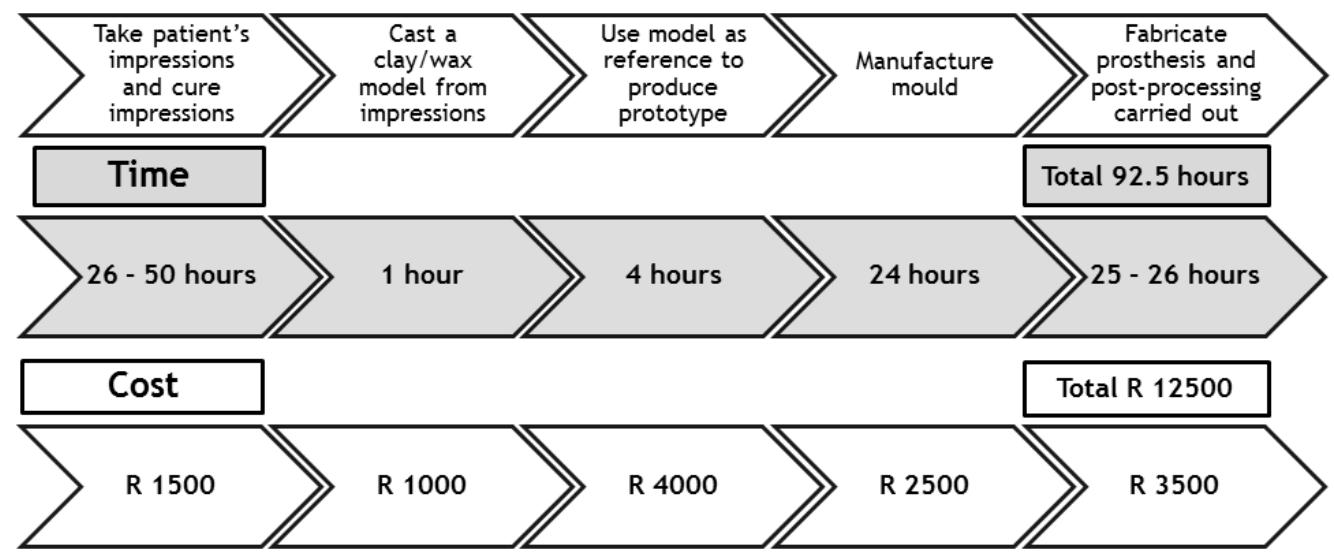

Figure 2: Process chain showing the traditional method of production in developed regions (adapted from Liacouras et al. [12])

Research by Liacouras et al. [12], and Maver, Botolin, and Gazvoda [23] has shown that the first four steps of the traditional method can be replaced with 3D scanning and AM. A digital mock-up can be created from which a mould can be manufactured with an $A M$ machine, and finally the silicon can be poured into the mould to form the prosthesis. Research by Liacouras et al. [12] carried out for ear prostheses verified that a process chain using 3D digitising and AM can be used. This is shown in Figure 3. 


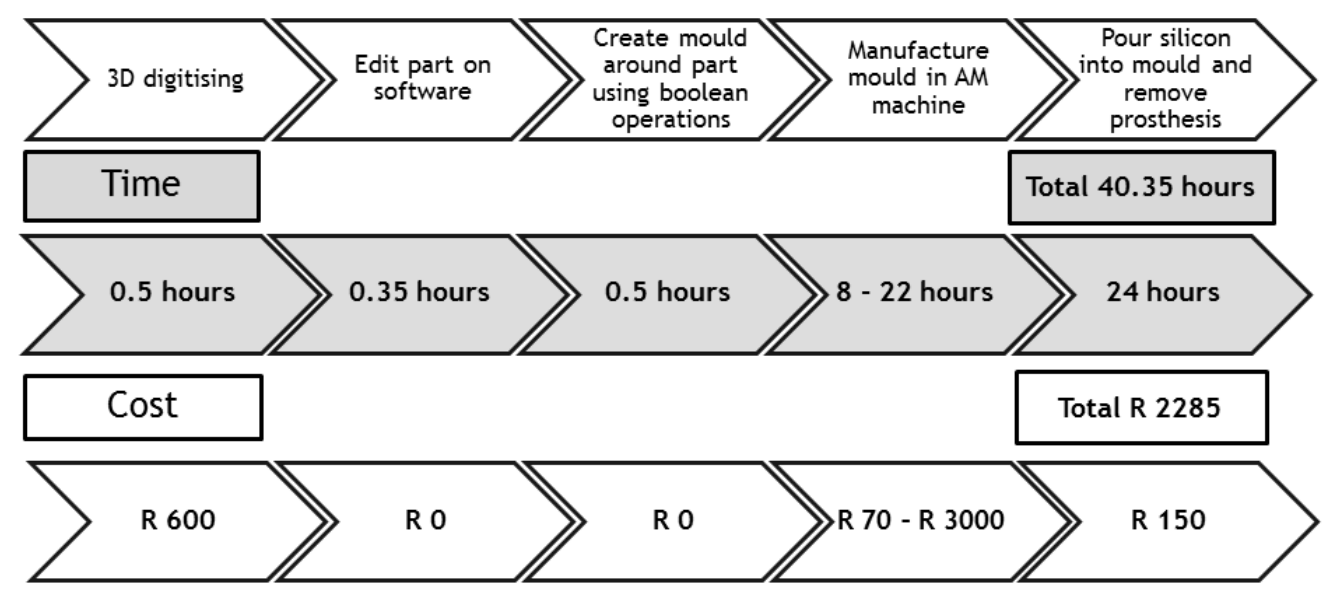

Figure 3: Suggested resource-efficient process chain showing the production of a prosthetic finger using $3 \mathrm{D}$ digitising and $\mathrm{AM}$

The modern resource-efficient process chain indicates a marked reduction in the time and cost of the manufacturing process. The time has decreased from an average of 92.5 hours to an average of 40.35 hours (saving 52.15 hours) by using the resource-efficient process chain. There is also a difference in costs, with the traditional method costing about R 12500 , while the suggested resource-efficient method costs an average of R 2285 (saving an average of R 10215 ).

\subsection{Process chain to manufacture a prosthetic finger using 3D digitising and AM technologies}

The process chain that was established for this study is shown in Figure 4.



Figure 4: Process chain established for the production of prostheses using 3D digitising and AM technologies

The process chain started with a 3D scan of the finger using a Kreon KLS51 laser line scanner that was mounted on a Zeiss CMM arm. The patient placed their finger on the CMM bed to reduce movement during the scan. Once the scan was completed the file was imported into 3-Matic software to carry out the file correction. A Boolean operation was used to obtain a mould-like structure and to achieve the slicing of the mould. The STL files of the two halves of the mould were then sent to the respective AM machine platforms. The machine setups were carried out to build the parts with a standard layer thickness. Next, the parts were built and removed from the machine. The open-source FDM mould required some post-processing, and the SLA mould required a post-UV cure. The silicon was then poured into the moulds and left to cure, after which the fingers were removed. 


\subsection{Time}

The time required to produce the prosthesis using each technology is important to determine the expected lead time for a prosthetic finger. Figure 5 shows the production time for each AM technology for the specific tasks. The respective times taken were 47.1 hours for open-source FDM, 44.7 hours for FDM, 30.9 hours for 3DP, and 41.5 hours for SLA. The traditional method uses a different process chain, and has an average lead time of two to three weeks (average of 92.5 hours).



Figure 5: Bar chart showing the production time of the prosthetic fingers using the newlyestablished process chain

The production of fingers using the modern $3 \mathrm{D}$ digitising and $\mathrm{AM}$ techniques indicates a very large decrease in production time when compared with the traditional processes. The production process using the 3DP technology was the quickest of the modern techniques by more than 10 hours (30.9 hours). The production process using the open-source FDM technology was the slowest (47.1 hours). As far as the modern techniques are concerned, the 3DP technology performed the best.

\subsection{Cost}

The costs for the newly-established process chain were calculated using the equations in section 3.1. These results should be put alongside the traditional cost of $R 12500$, which cannot be broken down and compared with the newly-established process chain because the processes are completely different. Figure 6 shows the costs of the 3D scanning and AM technologies in producing prosthetic fingers.

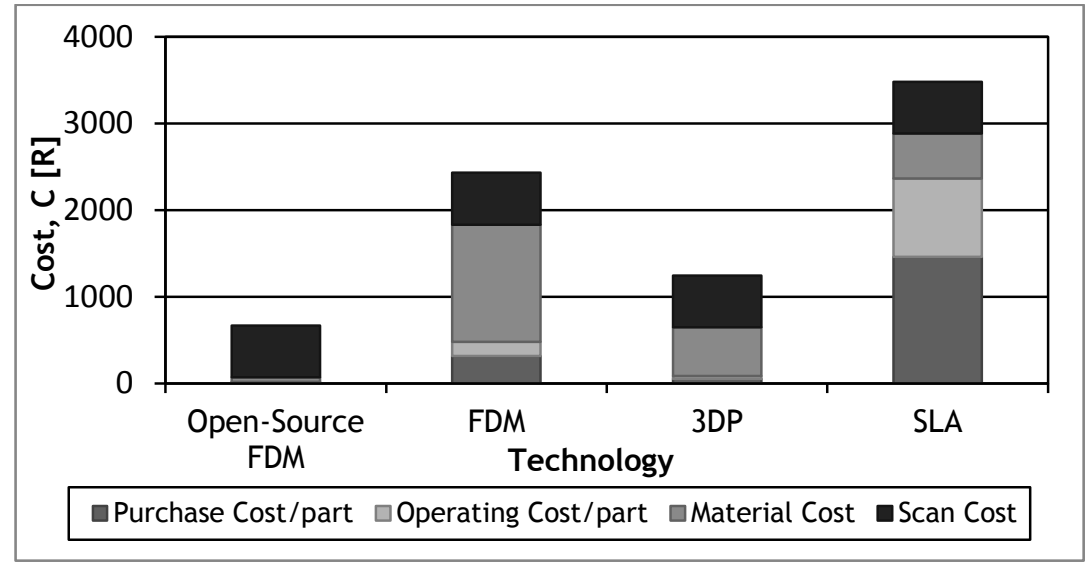

Figure 6: The resulting part cost of the respective fingers produced from the newlyestablished process chain 
The cost of producing a prosthetic finger using a process chain incorporating the open-source FDM technology ( $R$ 670) was almost a quarter of the commercial FDM process costs ( 22435$)$. The costs were spread over a fairly broad range. The second-cheapest technology was the 3DP (R 1248$)$, followed by the commercial FDM (R 2435 ), and finally by the SLA (R 3485 ). These figures are significantly lower than the cost of a prosthesis produced using the traditional method in developed regions (R 12 500).

\subsection{Total material usage}

Figure 7 shows the results of the material usage for the process chains for both the advanced technologies and the traditional method.

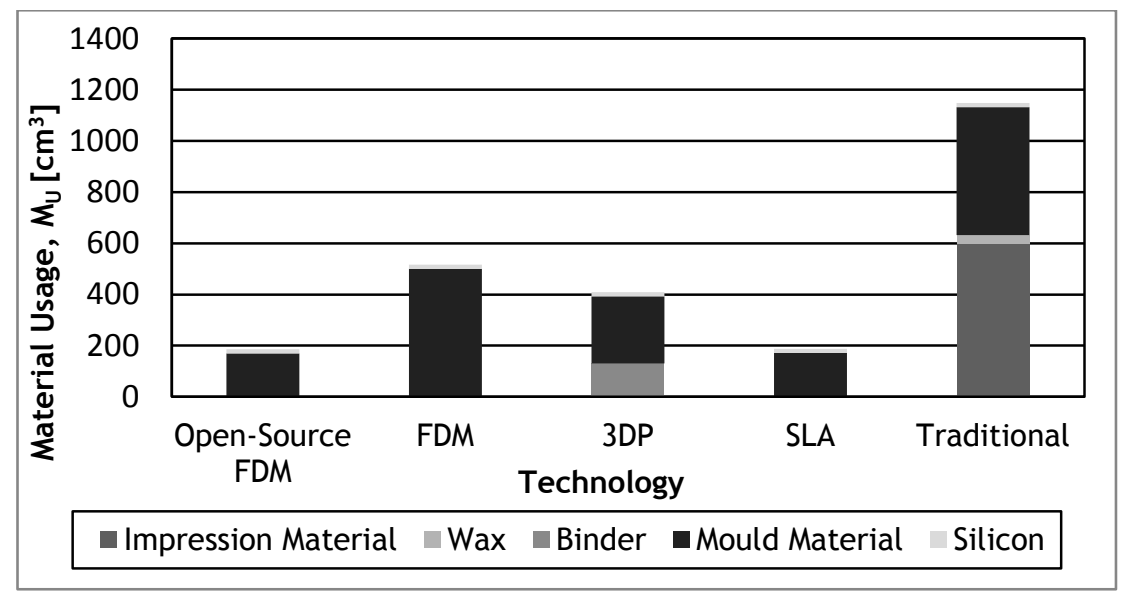

Figure 7: The material usage of the respective fingers produced from the newly-established process chain and the traditional method

The material usage for any process is important, as it determines the amount of material that must be stored, and the amount of material that must be disposed of in an environmental-friendly manner. The traditional method used more than double the amount of material used by the AM processes. The process chain using the FDM technology used the most material for the AM process chains. The open-source FDM and SLA processes used the least material. Examining the results obtained from the time, cost and material usage graphs, the open-source FDM and the 3DP processes are in close contention for the most favourable AM process.

\subsection{Quality}

The surface waviness profiles and surface roughness of the $A M$ moulds were measured and compared with each other. The traditional method was not compared here, as the moulds produced by a professional prosthetist have inconsistent surface features and a varying surface roughness. Table 2 shows the waviness profile of each of the surfaces produced by the respective AM technologies.

The surface produced by the open-source FDM machine showed a consistent series of five peaks, repeated over the measurement length. The level of the peaks increased and decreased in a consistent manner, forming a consistent wavy surface. Although the peaks vary in height across an individual series, the heights of the corresponding peaks in the different series are fairly consistent.

The surface produced by the commercial FDM technology showed a consistent series of five peaks repeated over the measurement length. Similar to the open-source FDM surface, the peaks from the FDM surface also rose and dropped in level over the five-peak series. The difference in the level between the lowest and highest peak was considerably less than that for the open-source FDM. The oscillating waviness profile was evident, due to the consistent rising and lowering of the heights of the crests. The waviness profile of both the FDM and open-source FDM was repeated every five crests, suggesting that this is a feature of the FDM process. 
Table 2: Waviness profiles of the surfaces produced by each of the AM technologies

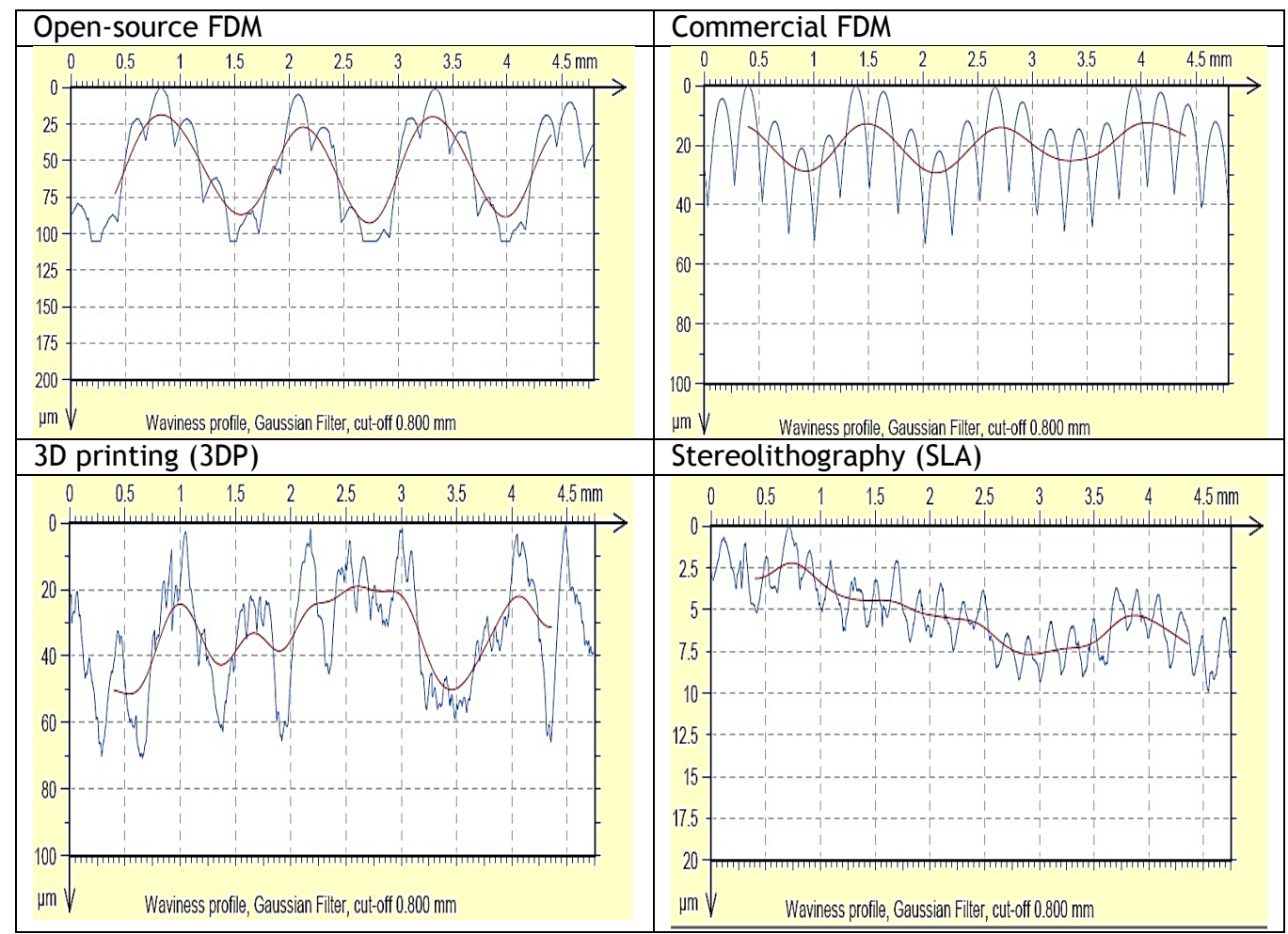

The surface produced by the 3DP technology exhibited sharp spikes and a highly erratic surface with no clear patterns. An irregular waviness profile was created by this technology, caused by the powder-based nature of the technology.

The surface produced by the SLA technology showed very small consistent crests throughout the surface. The crests are triangular in shape, compared with the inverted parabolic shape of the FDM processes. The waviness profile was fairly constant, and the range varied only within a few microns. This indicates that the SLA-produced surface closely correlates with the CAD model. The average roughness of each of the surfaces produced by the $A M$ technologies is shown in Figure 8 below.

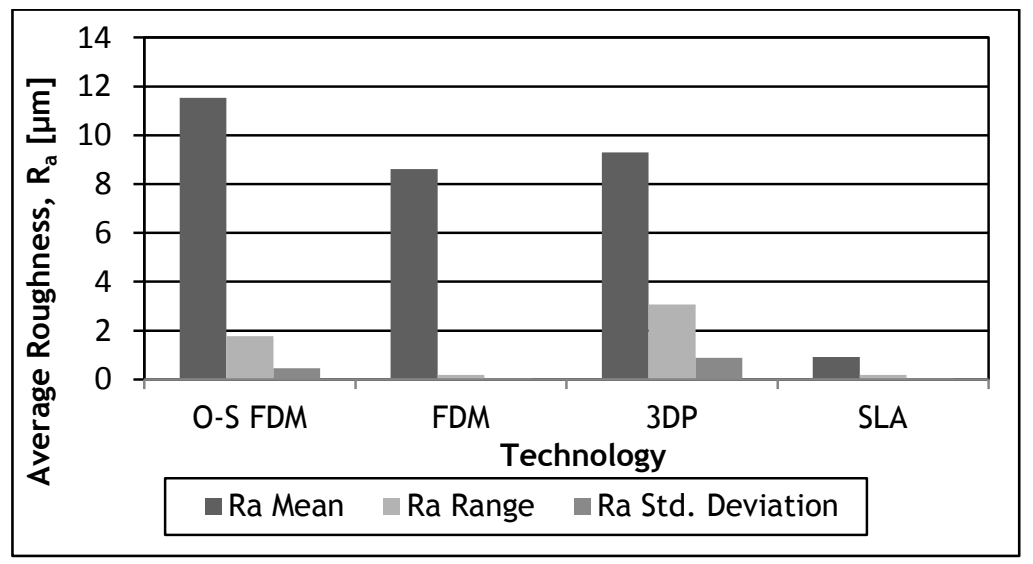

Figure 8: Bar chart showing the results obtained for the average roughness for each AM produced surface 
The results indicated that the open-source FDM produced the highest average roughness values, followed in turn by the 3DP, the commercial FDM, and the SLA. It must be noted that, although the 3DP process values are lower than those of the open-source FDM and slightly greater than the commercial FDM process, the layer thickness was $0.1 \mathrm{~mm}$ versus $\sim 0.25 \mathrm{~mm}$. This result shows that a higher roughness value per layer thickness is produced by 3DP technologies, with a greater standard deviation of average roughness. The SLA produced very low average roughness values, indicating a very smooth surface. The layer thickness chosen was $0.1 \mathrm{~mm}$ - the same as that for the 3DP - yet a much smoother surface resulted.

The maximum roughness of each of the surfaces produced by each of the $A M$ technologies is shown in Figure 9, along with the range and standard deviation of the measurements.

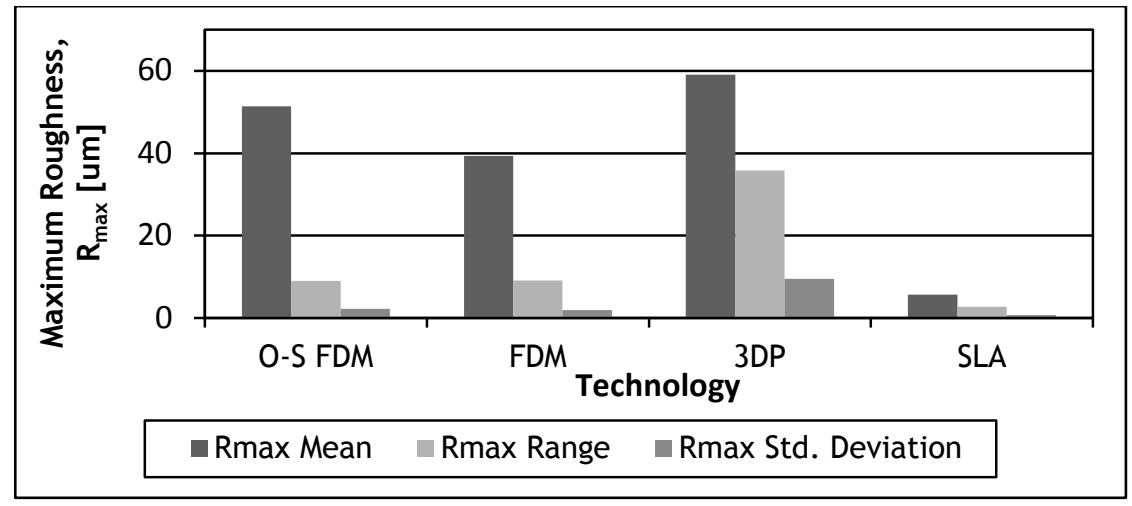

Figure 9: Bar chart showing the results obtained for the maximum roughness for each AMproduced surface

The maximum roughness is sensitive to surface flaws and surface inhomogeneity. The 3DP technology produced a surface with the greatest maximum roughness values, followed in turn by the open-source FDM, the commercial FDM, and the SLA technology. The powder-based nature of the 3DP led to the highest values. The open-source FDM and commercial FDM processes exhibit oscillating crests, as discussed previously. This is expected to cause high maximum roughness values. The SLA surface has a very low maximum roughness value, indicating that the surface is smooth along the evaluated length.

\subsubsection{Aesthetic quality of final prosthesis}

The aesthetic quality of the fingers produced was a very important consideration in this study. A more realistic-looking prosthesis would increase the probability of the patient accepting the prosthesis, and would promote a healthy mental attitude to the missing finger. A visual inspection was done by a professional prosthetist, comparing the results from the different technologies. The comparison of the 3DP finger and the SLA finger can be seen in Figure 10.
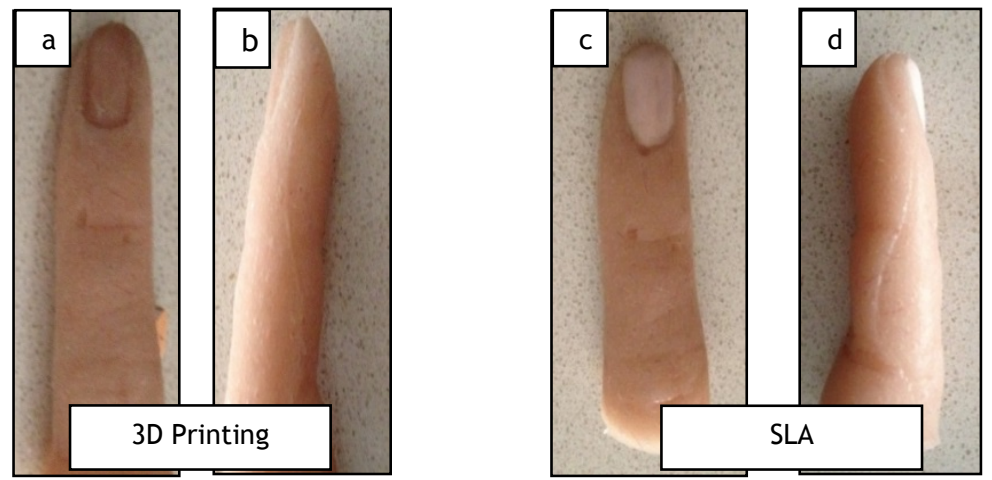

Figure 10: Comparison of 3DP finger (left), (a) top, (b) side view with SLA finger (right), (c) top, (d) side view 
The results indicate that, in respect of aesthetic quality (smooth surface, fine features, defects, realistic), the mould produced by the SLA technology produced the best prosthetic finger. The 3DP technology and the traditional method used in developed communities ranked second. The commercial FDM technology produced the next-best results, followed by the open-source FDM. Figure 11 shows the mould produced by SLA technology with Accura ${ }^{\circledR}$ SI50 ABS resin, and the resulting finger.

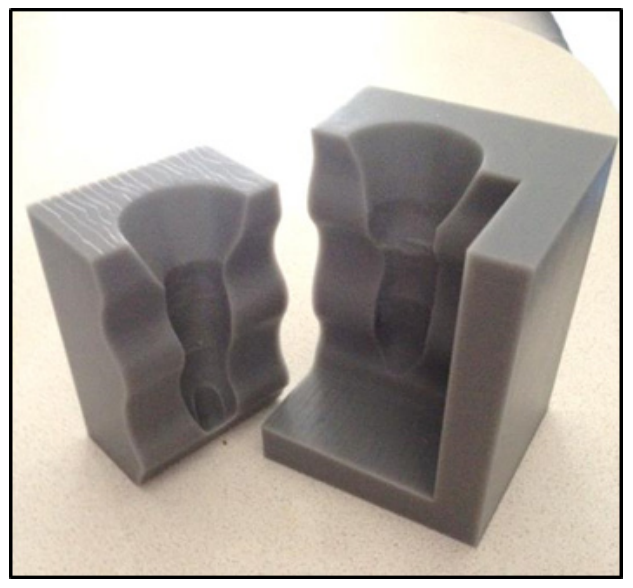

Figure 11: SLA mould (left), and (a) top, (b) bottom and (c) side view of the resulting finger (right)

The surface of the finger showed very fine detail, making it appear very life-like. No damage was done to the finger or the mould during the separation of the finger, and the detail from the mould was very neatly transferred to the silicon finger. The SLA finger was by far the most realistic, having the aesthetic quality of a finger produced by a highly-skilled prosthetist. A summary of the results for time, cost, material usage and quality can be seen in Table 3 below.

Table 3: Summary of the results for time, cost, material usage, and quality

\begin{tabular}{|l|l|l|l|l|}
\hline Method used & $\begin{array}{l}\text { Time } \\
{[\text { hours }]}\end{array}$ & $\begin{array}{l}\text { Cost } \\
\text { [ZAR] }\end{array}$ & Material usage $\left[\mathrm{cm}^{3}\right]$ & $\begin{array}{l}\text { Quality } \\
{[\text { rank }]}\end{array}$ \\
\hline $\begin{array}{l}\text { Traditional } \\
\text { method }\end{array}$ & 92.5 & 12500.00 & 1148.00 & 2 \\
\hline Open-source FDM & 47.1 & 670.00 & 186.15 & 4 \\
\hline $\begin{array}{l}\text { Commercial } \\
\text { FDM }\end{array}$ & 44.7 & 2435.00 & 516.26 & 3 \\
\hline 3DP & 30.9 & 1248.00 & 408.50 & 2 \\
\hline SLA & 41.5 & 3485.00 & 187.73 & 1 \\
\hline
\end{tabular}

\section{CONCLUSION}

This research was done to gain a better understanding of various additive manufacturing technologies for the resource-efficient production of prosthetic fingers in developing communities. It involved establishing a resource-efficient process chain for producing moulds to create prosthetic fingers, and the comparison of various $A M$ technologies for time, cost, material usage, and quality. The additive manufacturing technologies included open-source FDM, commercial FDM, 3DP, and SLA.

The production of prostheses in developing communities, and research into the use of modern methods in the prosthesis production chain, were investigated. The 3D digitising and $A M$ technologies were investigated to gain an in-depth understanding of the basis on which each of the various technologies functions.

An experimental setup and design were then established to carry out the investigation. An experimental process chain for the production of finger prostheses was presented, and the moulds 
and corresponding fingers were analysed and tested. The time, cost, material usage, and quality using each of the additive manufacturing technologies were presented. The surface topography of each of the moulds was investigated to detect whether the technology was appropriate for mouldmaking in the field of prosthetics. The aesthetic quality of each of the fingers produced was evaluated to determine which technologies produced acceptable results.

The aesthetic results obtained for the production of a prosthetic finger using open-source FDM technology were poor, compared with the other $A M$ technologies. However, the prosthetic finger did resemble a real finger, and proved to be a better solution than the techniques currently used in developing communities.

Although the SLA produced the best results, the cost of producing a prosthetic finger using this technology was relatively high. Similarly, although the open-source FDM technology produced a relatively inexpensive prosthetic finger, the aesthetic quality was relatively poor. The 3DP technology produced a very good prosthesis with aesthetic quality at a fairly low cost, with a fast build time and low material usage. This made the 3DP technology the best candidate for the production of prosthetic fingers in developing communities.

Considering the high costs of prostheses produced using traditional methods in developed communities ( $R 12500$ ), the advanced $A M$ technologies were a better solution because of their favourable aesthetic quality and lower cost (R 1248$)$. In particular, the SLA technology was the most suitable to emerge from this experiment for higher cost ( $R 3485$ ) prostheses, due to the excellent aesthetic quality. Using the resource-efficient process chain, there is an average time saving of 52.15 hours and an average cost saving of R 10215 , depending on the technology used.

The material usage, production time and cost of all technologies were lower than those for the traditional method. This result is significant: the cost of the prosthesis is reduced, and the aesthetic quality is improved. It must be noted, however, that some prosthetic services can provide extremely life-like prosthetic fingers at a very high cost.

\section{REFERENCES}

[1] Oosthuizen, G., Butala, P., Böhm, S., Rebensdorf, A. and Gergert, A. 2014. Open community manufacturing, SAIIE26 Proceedings, Muldersdrift.

[2] Bartolo, P., Kruth, J., Silva, J., Levy, G., Malshe, A., Rajurkar, K., Mitsuishi, M., Ciurana, J. and Leu, M. 2012. Biomedical production of implants by additive electro-chemical and physical processes, CIRP Annals - Manufacturing Technology, 61(2), pp. 635-655.

[3] Vorvick, L.J. 2013. 'Medline Plus', A service of the U.S. National Library of Medicine, 21 January 2013. [Online]. Available: http://www.nlm.nih.gov/medlineplus/ency/article/ 002286.htm. [Accessed 20 February 2015]

[4] Burger, H. and Maricek, C.R. 2007. Disability and rehabilitation: Return to work after lower limb amputation, Disability and Rehabilitation, 29(1), pp. 1323-1329.

[5] Desmond, D. and MacLachlan, M. 2002. Psychological Issues in the field of prosthetics and orthotics: A 25 year review, Prosthetics and Orthotics, 26(3), pp. 182-188.

[6] Carroll, A. and Fyfe, A. 2004. A comparison of the effect of the aesthetics of digital cosmetic prostheses on body image and well-being, Journal of Prosthetics and Orthotics, 16(2), pp. 66-68.

[7] Pillet, J. 2001. Aesthetic hand prosthesis: Gadgets or therapy, The Journal of Hand Surgery, 28, pp. 523528.

[8] Botolin, L. 2007. Use of rapid manufacturing technology in comprehensive rehabilitation of a patient with physical body disorders, in 11th Mediterranean Conference on Medical and Biomedical Engineering and Computing, Ljubljana

[9] Biddiss, E. 2007. Consumer design priorities for upper limb prosthetics, Disability and Rehabilitation, 2(6), pp. 346-357.

[10] Quinton, D. and Pilley, M. 1999. Digital prostheses for single finger amputations, Journal of Hand Surgery, 24(5), pp. 539-541.

[11] Oosthuizen, G., Hagedorn-Hansen, D. and Gerhold, T. 2013. Evaluation of rapid product development technologies for production of prosthesis in developing communities, in Proceedings of SAIIE 25, Stellenbosch.

[12] Liacouras, P., Garnes, J., Roman, N., Petrich, A. and Grant, G.T. 2011. Designing and manufacturing an auricular prosthesis using computed tomography, 3-dimensional photographic imaging, and additive manufacturing: A clinical report, The Journal of Prosthetic Dentistry, 105(2), pp. 78-82.

[13] Gibson, I., Rosen, D.W. and Stucker, B. 2010. Additive manufacturing technologies, New York: Springer. 
[14] Ueda, K., Takenaka, T., Vancza, J. and Monostori, L. 2009. Value creation and decision-making in sustainable society, CIRP Annals - Manufacturing Technology, 58(2), pp. 681-700.

[15] Scott, J., Wohlers, T. and Caffrey, C. 2012. Additive manufacturing status and opportunities, Wohlers Associates, Fort Collins.

[16] Van Gestel, J.P., Cuypers, N., Bleys, S. and Kruth, P. 2009. A performance evaluation test for laser line scanners on CMMs, Optics and Lasers in Engineering, 47, pp. 336-342.

[17] Shu, C. and Xi, F. 1999. CAD-based path planning for 3-D line laser scanning, Computer Aided Design, 31, pp. 473-479.

[18] Levy, G.N., Schindel, R. and Kruth, J.P. 2003. Rapid manufacturing and rapid tooling with layer manufacturing technologies: State of the art and future perspectives, St Gallen: FHS University of Applied Sciences.

[19] Jacobs, P.F. 1992. Rapid prototyping \& manufacturing: Fundamentals of stereolithography, New York: Society of Manufacturing Engineers.

[20] Tang, Y. 2002. Stereolithography (SL) cure modelling, Georgia: Georgia Institute of Technology.

[21] Atzeni, A. and Salmi, E. 2012. Economics of additive manufacturing for end-usable metal parts, International Journal of Advanced Manufacturing Technology, 62, pp. 1147-1155.

[22] Eskom. [n.d]. Small power users [Online]. Available: http://www.eskom.co.za/CustomerCare/ TariffsAndCharges/Documents/Connect_A4_SPU1.PDF. [Accessed 01 February 2013]

[23] Maver, T., Botolin, L. and Gazvoda, S. Use of rapid manufacturing technology in comprehensive rehabilitation of a patient with physical body disorders, Digicen [Online]. Available: http://digicen.si/clanki/nasi_clanki/ICIT_07_784_botolin.pdf. [Accessed 25 January 2014] 